\title{
Petismo e lulismo na periferia de São Paulo: uma abordagem qualitativa
}

Camila Rocha

\section{Introdução}

O impedimento de Dilma Rousseff em abril de 2016 aprofundou ainda mais a crise vivenciada nos últimos anos pelo Partido dos Trabalhadores. No final de 2015, uma pesquisa interna do partido, realizada pela Fundação Perseu Abramo, já apontava que a extinção do PT era considerada por quase metade da população ${ }^{1}$. No entanto, sua principal liderança continua a se manter em primeiro lugar para a corrida presidencial de 2018 em todos os cenários, confirmando que o lulismo continua vivo apesar de tudo, o que parece corroborar a interpretação realizada pelo cientista político André Singer (2012) de que o lulismo é mais do que um fenômeno eleitoral.

A maior parte das análises políticas realizadas dentro e fora da academia procuraram explicar o sucesso do lulismo devido às políticas de transferência de renda, aumentos do salário mínimo e de crédito que teriam beneficiado a população mais pobre do país e colocado em marcha um processo de ascensão social em massa entre os anos de 2004 e 2014. No entanto, como pretendo argumentar no presente artigo, de acordo com dados levantados a partir de uma série de entrevistas em profundidade que realizei com moradores de um bairro de periferia da cidade de São Paulo que haviam ascendido socialmente a partir de 2004, as motivações alegadas pela preferência pelo PT e/ou por Lula não foram de ordem material, mas sim de ordem simbólica, tendo em vista os benefícios recebidos pela população mais pobre que habita o Nordeste brasileiro. Contudo, a despeito dessa identificação simbólica, a adesão ao PT e ao lulismo por parte dessa parcela do eleitorado está longe de ser incondicional e possui fragilidades importantes.

Para poder compreender melhor as percepções políticas dos entrevistados, faz-se necessário considerar suas experiências cotidianas tendo em vista tanto sua inserção de classe como o declínio da cultura política do petismo em seu local de moradia. Desse modo, primeiramente realizo uma breve discussão da bibliografia sobre lulismo e dinâmica de classes seguida da exposição da metodologia adotada na pesquisa para a seleção dos sujeitos pesquisados, posteriormente é abordado o declínio do petismo nos bairros de periferia de São Paulo, em particular na Brasilândia, bairro de moradia dos entrevistados, e, por fim, analiso as percepções políticas dos entrevistados acerca do lulismo, considerando seus potenciais e suas fragilidades.

\footnotetext{
1 Disponível em: <http://opiniao.estadao.com.br/noticias/geral,a-crise-estrutural-do-pt,10000051415>. Acesso em: 26 fev. 2018.
} 


\section{Dinâmica de classes e lulismo: conceitos e metodologia de pesquisa}

Para André Singer (2012), o lulismo seria um movimento político em que o então presidente Lula teria realizado uma arbitragem do conflito social e político combinando medidas que ao mesmo tempo teriam beneficiado os mais pobres, por meio de políticas de transferência de renda, e o grande capital, por meio da manutenção de políticas econômicas ortodoxas, modus operandi que teria sido herdado por Dilma Rousseff. Ideologicamente, o lulismo teria promovido mudanças sociais sem romper com a ordem social-econômica vigente, o que teria coincidido com a ideologia de mudança dentro da ordem compartilhada pelos setores mais empobrecidos do país, chamados por Singer de "subproletariado"2. Tal coincidência ideológica teria feito com que a adesão à figura de Lula fosse mais forte do que uma simples aprovação do governo de turno, desencadeando um realinhamento eleitoral, isto é, uma mudança de padrão eleitoral em que o subproletariado, que desde 1989 votava em sua maioria em candidatos à presidente mais conservadores, teria passado a votar em Lula e nos candidatos por ele apoiados, e a maior parte das classes médias e altas teria passado a votar de forma sistemática na oposição.

$\mathrm{O}$ ano de 2010 marcou o auge do lulismo. Lula deixava seu segundo mandato com popularidade recorde e o país desfrutava de baixos níveis de desemprego, de aumentos reais no salário mínimo e do crescimento explosivo do consumo entre famílias de baixa renda. No período entre 2006 e 2014, sob as presidências de Lula e Dilma Rousseff, as classes populares brasileiras participaram de um processo de mobilidade econômica em massa. Além da redução do número de pessoas consideradas miseráveis, desencadeada principalmente por conta dos programas de transferência de renda adotados pelo governo federal, houve um aumento dos níveis de renda e consumo de cerca de 52 milhões de trabalhadores pobres em decorrência, principalmente, dos aumentos do salário mínimo acima da inflação, da criação de milhões de empregos sobretudo nos setores da construção civil e de serviços, e do aumento da formalização (dois em cada três trabalhadores passaram a possuir carteira assinada) (Pochmann, 2012). O que constituiria uma explicação plausível para o sucesso de popularidade de Lula em 2010 e a relativa facilidade em eleger uma sucessora que sinalizasse a continuação das políticas adotadas em seus governos.

Em vários bairros de periferia da cidade de São Paulo, a bonança econômica se materializava no aumento do trânsito de carros e motos, na expansão do comércio local, na abertura de novas agências bancárias e no ânimo de muitos moradores para iniciar reformas em casa, adquirir eletrodomésticos, aparelhos eletrônicos e fazer viagens e cursos universitários. Tal cenário fez com que certos analistas políticos dentro e fora da academia passassem a considerar o surgimento de uma "nova classe $C^{\text {", }}$, tendo em vista a

\footnotetext{
2 A ideia de que o subproletariado se orientaria ideologicamente com base na fórmula "mudança dentro da ordem" foi proposta por Singer a partir de um conjunto de diversas pesquisas de opinião. Cf. Singer (2000).
} 
divisão da população em faixas de renda "A", "B", "C", "D" e "E"3 e o deslocamento em massa de pessoas da faixa D para a C, - ou mesmo de uma "nova classe média" (Neri, 2008; Lamounier e Souza, 2010) -, porém, tal ideia logo foi alvo de críticas, entre as quais se destacam as realizadas pelos sociólogos Souza (2010) e Braga (2012, 2015), os quais procuraram caracterizar esses setores das classes populares brasileiras de forma crítica, utilizando os conceitos de "batalhadores" e "precariado", respectivamente.

Para Jessé de Souza, os batalhadores seriam entusiastas das políticas de transferência de renda dos governos petistas e estariam dispostos a se submeter "a praticamente todo o tipo de superexploração da mão de obra" para ascenderem socialmente. Possuidores de uma economia emocional baseada em disciplina, autocontrole e pensamento prospectivo, que os diferenciaria de outros segmentos das classes populares, os batalhadores teriam conseguido acesso a novos patamares de consumo ao custo de "extraordinário esforço e sacrifício pessoal" (Souza, 2010, p. 327). Ruy Braga, porém, enxerga o entusiasmo com as políticas do governo Lula por parte dessa população, a qual denomina como "precariado", com maior reserva. Para Braga, a precariedade seria uma condição estruturante da classe operária de países, como o Brasil, que se industrializaram sob o fordismo periférico, daí a denominação de "precariado" proposta pelo autor para caracterizar os trabalhadores precarizados no país ${ }^{4}$, os quais, a despeito de passarem a desfrutar de um nível de consumo mais alto, continuam enfrentando "altas taxas de rotatividade, flexibilização, terceirização e acidentes de trabalho" e a pressão da exploração econômica e da ameaça de exclusão social (Braga, 2015, p. 92). Tal situação provoca o que Braga denomina de "inquietação operária", de modo que a avaliação positiva de certas políticas do lulismo seria fruto de um consentimento passivo e instável por parte dessa população, tendo em vista os sentimentos permanentes de frustração e insatisfação que a permeiam historicamente e que não teriam sido alterados de forma importante pelo processo de ascensão social.

Nesse ponto, a análise de Braga sobre o lulismo e a dinâmica das classes sociais se diferencia da realizada por André Singer, o qual defende que o aumento da formalização da inserção ocupacional ocorrido durante os governos petistas poderia apontar para uma passagem de parte do subproletariado para o proletariado, afinal, a posse de carteira assinada e o acesso a sindicatos representariam uma característica fundamental do proletariado em oposição ao subproletariado e garantiriam um patamar mínimo a partir do

\footnotetext{
3 O Critério de Classificação Econômica do Brasil (CCEB), elaborado pela Associação Brasileira de Empresas de Pesquisas (Abep), busca estimar o poder de compra das pessoas com base em seus níveis de renda familiares, considerando uma família de quatro pessoas. Assim, no ano de 2013, integrariam os segmentos " $E$ " e " $D$ " as famílias com renda média mensal de $R \$ 776,00$, o " $C$ " aquelas com renda entre $R \$ 1.147,00$ e $\mathrm{R} \$ 1.685,00$; e os segmentos " $\mathrm{B}$ " e " $\mathrm{A}$ " as famílias que somavam, respectivamente, uma renda de $\mathrm{R} \$$ $2.654,00$ e de $\mathrm{R} \$ 9.263,00$.

${ }^{4}$ É importante frisar que, ao contrário de Standing (2013), que, a partir de uma análise da dinâmica de classes de países europeus, propõe que o precariado seria uma nova classe diferente da classe trabalhadora tradicional, Braga defende que no Brasil, assim como em outros países do sul global, o precariado seria intrínseco às classes trabalhadoras há muito tempo, tendo em vista a precariedade histórica das condições de vida e trabalho desses países.
} 
qual os trabalhadores poderiam se organizar. Desse modo, para o cientista político, a inquietação operária teria passado a se expressar de forma mais contundente por causa da ascensão social do subproletariado para o proletariado desencadeada pelo lulismo, e não por conta da inserção precarizada dessa população em si, como afirma Braga.

Durante minha pesquisa de campo, realizada entre 2011 e 2013, foi possível constatar a validade do diagnóstico feito por Braga no que diz respeito aos sentimentos permanentes de inquietação e frustração, presentes antes e depois do processo de ascensão social e relacionados à inserção ocupacional precária, e ao consentimento passivo e instável em relação ao lulismo apontado pelo sociólogo, daí minha opção em utilizar o conceito de precariado para qualificar a população investigada ${ }^{5}$. Ao longo de dois anos e meio conduzi duas rodadas de entrevistas em profundidade com 17 moradores $^{6}$ do bairro de Brasilândia, localizado na Zona Noroeste da cidade de São Paulo, sobre sua história de vida, experiências cotidianas e percepções políticas. A primeira rodada ocorreu no segundo semestre de 2011 e a outra após as eleições municipais, entre o final de 2012 e o início de 2013. Todos os entrevistados eram maiores de 18 anos, trabalhavam principalmente na construção civil e no setor de serviços (comércio, limpeza e serviço doméstico), haviam passado a fazer parte da faixa " $C$ " de rendimentos a partir de 2006 e votavam no município de São Paulo. Além disso, como meu objetivo era entrevistar eleitores comuns, nenhum dos 17 entrevistados era filiado a partidos ou participava de outras organizações e movimentos políticos.

Foi possível entrevistar pessoas cujo perfil correspondesse ao dos moradores do bairro, de maioria católica e negra, de acordo com a pesquisa DNA Paulistano realizada pelo Instituto Datafolha em 2008, e fosse variado em termos de idade. Contudo, o número de mulheres entrevistadas acabou sendo maior que o de homens, pois a maior parte destes trabalhava em mais de um emprego e, muitas vezes, durante os finais de semana, justamente o período em que a pesquisa era realizada.

Minha escolha em conduzir a investigação na Brasilândia em detrimento de outras localidades com perfil similar ocorreu em virtude da existência de dois informantes de pesquisa que poderiam me ajudar a acessar o bairro e seus moradores. Contudo, no início da pesquisa, as dificuldades em conversar com as pessoas e realizar entrevistas fizeram com que um dos meus informantes iniciais resolvesse me apresentar a alguém que poderia me ajudar mais com a pesquisa porque conhecia muitas pessoas do bairro. Foi assim que conheci Vânia7, uma ex-militante de base do PT que passou a frequentar a Comunidade de

\footnotetext{
5 Para além disso, as pessoas entrevistadas durante a pesquisa de campo se encaixavam de forma mais adequada ao conceito de precariado do que aos conceitos de batalhadores e subproletariado, tendo em vista as características estruturais propostas por Braga. Para mais detalhes sobre as diferenças existentes entre as três categorias cf. Braga (2012, p. 28).

${ }^{6}$ A quantidade de entrevistados foi determinada em função da própria dinâmica da pesquisa, isto é, à medida que as falas dos entrevistados foram se tornando cada vez mais parecidas e que diferentes perfis foram cobertos, percebi que não havia necessidade de continuar a entrevistar mais pessoas.

7 Os nomes de todos aqueles que foram entrevistados para a pesquisa, com exceção de Juçara Zottis, figura pública da Associação Cantareira, foram modificados para proteger suas identidades. Cada trecho de entrevista aqui exposto é seguido do nome, idade e ano em que a entrevista foi coletada.
} 
Base do seu bairro nos anos 1980 e que, por conta de seu ativismo, conhecia muito bem sua vizinhança e me acompanhou em praticamente todas as entrevistas, o que reduziu significativamente os potenciais efeitos negativos da distância social que existia entre mim e os entrevistados.

À medida que o trabalho de campo avançava, percebi que cerca de um terço dos entrevistados havia tido algum contato com a cultura política do petismo nos anos 1980 ou 1990, e que esse contato foi importante para uma identificação inicial com o partido e suas lideranças. Desse modo, resolvi pesquisar de forma mais detida a história do petismo no bairro. Para tanto realizei uma pesquisa documental que reuniu dezenas de publicações sobre a região, cedidas por duas ONGs, o Centro de Estudos e Pesquisas em Educação, Cultura e Ação Comunitária (Cenpec) e a Associação Cantareira, localizada na Brasilândia e liderada por uma ex-militante do PT e do Movimento dos Trabalhadores Sem Terra (MST), Juçara Zottis. Além disso, também entrevistei Juçara Zottis e Cecília, que foi companheira de militância de Vânia nos anos 1980 e 1990 e ainda continuava na ativa, bem como a própria Vânia, que por vezes também dialogava com alguns dos moradores durante as entrevistas. A partir desse material, especialmente daquele levantado para a seção "De olho na história", do Jornal Cantareira, foi possível verificar como os próprios moradores e militantes da Brasilândia compreendiam a história política do bairro, a qual, a partir dos anos 1970 e 1980, passou a ficar entrelaçada com a história do petismo no local ${ }^{8}$.

\section{O declínio do petismo: do refluxo das mobilizações à decepção com a corrupção}

O "petismo" é compreendido aqui como uma cultura política específica ligada ao Partido dos Trabalhadores. Assim, diferentemente do que propõe o cientista político Samuels (2004), aqui a adesão a tal cultura não se limita a possuir preferência pelo PT e votar consistentemente no partido, mas fazer, pensar e viver a política tendo em vista a valorização da mobilização popular, a transparência e ética; e a implementação de políticas voltadas para as classes populares. Nesse sentido específico, nem todo militante ou eleitor fiel do PT necessariamente partilharia do petismo, uma vez que essa não é a única cultura política que existe no partido, ainda que sua existência tenha sido bastante relevante em seus primeiros anos de fundação.

Inicialmente o petismo ganhou um maior número de simpatizantes entre as classes médias intelectualizadas e progressistas e entre grupos de trabalhadores que moravam em bairros próximos às cidades do $A B C$, região onde ocorreram as famosas greves do final dos anos 1970 (Frizzo, 2013). Com o tempo, tal cultura espalhou-se pouco a pouco para outros bairros de periferia por meio de padres e freiras que atuavam nas Comunidades

\footnotetext{
${ }^{8}$ É importante ressaltar que a análise das entrevistas realizada aqui é de conteúdo e não de discurso.
} 
Eclesiais de Base (CEBs) (Macedo, 1986) e de militantes de movimentos sociais e/ou do próprio partido, como ocorreu na Brasilândia.

Durante a década de 1970, em plena ditadura militar, começaram a surgir na região diversos movimentos de moradores para reivindicar melhorias, muitos dos quais estavam ligados à Igreja Católica. A Igreja se expandiu na região por meio da fundação de diversas CEBs: a primeira, Santa Isabel, foi fundada ainda no fim da década de 1960, depois vieram a CEB Sant'Ana em 1983, a CEB São Renato Batista em 1986, a CEB Sagrado Coração de Jesus em 1991, entre outras. De acordo com os depoimentos de militantes dos movimentos de moradores coletados pelo Jornal Cantareira, edição de fevereiro/março de 2003, seção "De olho na história: Vila Brasilândia, meio século de contradições", essa época foi politicamente marcante para a região:

Eram grupos heterogêneos oriundos da Igreja, da Frente Nacional do Trabalho, do movimento estudantil, que envolvia também professores, militantes políticos, líderes de movimentos, padres, irmãs e agentes da pastoral que iniciam uma luta de resistência e enfrentamento aos grupos de direita que comandavam a região. Foi uma década muito importante no processo de formação política da Brasilândia. Nesse momento a Igreja Católica estava em comunhão com o sofrimento do povo. Era o início da Teologia da Libertação, o começo das Comunidades Eclesiais de Base (CEBs) e da organização das pastorais sociais (Luiz Zimmerman).

A luta pela água foi um dos principais motivos que desencadeou o movimento de resistência na região. Problemas como canalização de esgoto, luz, transporte público, regularização dos terrenos, a falta de equipamentos públicos (posto de saúde, escolas, creches, centros culturais) tomou um contexto amplo que envolveu quase todos os bairros do subdistrito Brasilândia. A organização dos diversos bairros ganhou força e a Brasilândia era vista como um caroço na garganta dos governantes. As lideranças e o povo não davam trégua enquanto não fossem atendidas as reivindicações. Esse ciclo durou aproximadamente 15 anos. A luta foi longa, mas de uma em uma o povo conquistou todas as reivindicações (Teresa Lajolo).

Para alguns moradores que frequentavam a Igreja, as CEBs acabavam servindo, por vezes, como porta de entrada para o mundo da política partidária, tendo em vista os laços existentes entre várias lideranças religiosas que atuavam nessas Comunidades e no Partido dos Trabalhadores:

A comunidade acolhe, a comunidade tem lugar para as pessoas sentarem, tem banheiro, tem água para as crianças. Quando as pessoas chegavam, sem teto, o que o padre Guilherme fazia? Doava um pedacinho do terreno para as pessoas, as pessoas construíam, moravam, quando estavam estabilizadas, 
vendiam ali e iam para outro lugar melhor. $O$ padre Guilherme também gostava de alguma política... (Célia, 49 anos, 2011).

Dulce: eu só voto nesse povo do PT, já te disse, só não sei explicar por quê...

Vânia: Tem gente que foi muito influenciada pela irmã Natalvina...

Dulce: Acho que sim...

Vânia: Acho que isso fez com que a gente despertasse interesse pelo PT. O padre Guilherme e a irmã Natalvina sempre apoiaram o PT. Eu fui filiada porque a irmã convenceu a gente de que o PT era melhor, e aí tem aquela influência também de que é o Partido dos Trabalhadores, e o que nós somos? Trabalhadores (Vânia, 47 anos, Dulce, 52 anos, 2011).

Maria Ferreira era a mulher que tocava violão na (CEB) Santo Eugênio. Faz muito tempo, vai fazer uns 6 ou 7 anos que ela faleceu. Uma pessoa maravilhosa, ela dava crisma, catequese e ela tocava violão também. Ela trabalhava com as freiras na creche, era diretora da creche. Mas parecia até uma freira mesmo, porque era uma pessoa tão bondosa, ensinava a gente, dava um incentivo, era uma mulher muito inteligente, fez pós, fez tudo, tanto que ela ia se candidatar para ser vereadora do bairro, eu acho que era pelo PT (Eliana, 30 anos, 2011).

Porém, já no final dos anos 1980, mas principalmente durante a década de 1990, os movimentos de bairro e as CEBs foram perdendo força. Os motivos para que isso tenha ocorrido são vários, entre os quais é possível apontar a mudança da atuação da própria Igreja Católica nos bairros de periferia, tendo em vista a perda de espaço da teologia da libertação e o avanço do movimento carismático (Sofiati, 2009). Porém, o fator principal por trás do declínio dos movimentos, e do próprio petismo, foram os cortes promovidos na indústria durante o período, o que resultou em altas taxas de desemprego e na dificuldade de organização dos trabalhadores (Feltran, 2011).

É possível dizer que, entre os trabalhadores moradores de bairros de periferia, o "petismo" andava de mãos dadas com o que o sociólogo Feltran (2011) chamou de "projeto do trabalhador", um projeto de ascensão social via participação em movimentos sociais, autoconstrução da moradia e trabalho fabril. A adesão a esse projeto por vários moradores de bairros de periferia de grandes cidades, vindos em sua maior parte de regiões empobrecidas do país, foi possível durante as décadas de 1970 e 1980 por conta de uma conjuntura política e econômica específica, que combinava abertura política, e portanto maiores possibilidades de organização sindical e protesto social, e uma oferta razoável de empregos na indústria que garantia as condições materiais para que muitos homens pudessem sustentar sozinhos suas famílias, como pude constatar em minha 
pesquisa.

No entanto, a adoção de políticas voltadas para a abertura do mercado brasileiro a partir do início da década de 1990 prejudicou vários setores da indústria nacional, resultando em altas taxas de desemprego, especialmente nas regiões metropolitanas (Diniz e Boschi, 2004):

Eu trabalhei uns 20 anos em metalúrgica. Em São Paulo eu peguei firma boa, convênio médico, restaurante bom... depois deu uma caída. [O governo FHC] foi péssimo também, não gostei não, foi uma época que foi péssimo pra emprego. Foi nessa época que eu fiquei desempregado... entrava em todas as firmas e não estavam pegando ninguém, não tinha emprego nenhum. Eu encontrava colegas na rua tremendo de raiva, eu falava "calma rapaz, vai pra casa né? Amanhã é outro dia, não é não?". As firmas avisavam: "não há vaga", "não tem emprego" (Raimundo, 53 anos, 2011).

Eu trabalhei em várias firmas, porque antes era muito fácil a gente arrumar emprego. Você trabalhava numa indústria e não gostava do serviço você já arrumava outro, era muito fácil, trabalhava um ano em uma firma, dois anos em outra... A última firma em que eu trabalhei, eu trabalhei dez anos, eu saí de lá em 1996, teve esse corte em que eles mandaram muita gente embora, aí depois disso eu não consegui mais. Eu fiz teste em outra firma, também de costura, mas aí eu não passei. É... então aí foi complicando, não consegui mais e deu no que deu... (Ana Maria, 52 anos, 2011).

Desempregados ou trabalhando em condições extremamente precárias, os moradores de bairros de periferia passaram a buscar a resolução de seus problemas de forma estritamente individual por meio de diversas saídas de emergência, recorrendo, por exemplo, aos laços familiares e à ajuda de igrejas evangélicas, e não mais à organização coletiva, como ocorria no período anterior (Cabanes et al., 2011). Essa situação, agravada por fatores como o crescimento do tráfico de drogas e da criminalidade nas periferias das grandes cidades, fomentou um refluxo dos movimentos populares e da militância política de base do PT, o que fez com que a adesão ao projeto do trabalhador fosse ficando cada vez mais insustentável, até se tornar praticamente residual (Feltran, 2011).

O abandono do "projeto do trabalhador" se refletiu no início do declínio progressivo do petismo entre as classes trabalhadoras a partir da metade da década de 1990 em diante. Tal declínio foi paulatinamente sendo reforçado pelas mudanças internas do PT relacionadas à profissionalização dos quadros partidários e à diminuição do espaço para a militância de base, as quais contribuíram para que o partido passasse a se voltar mais para seus objetivos eleitorais imediatos (Secco, 2011), moderando progressivamente seu discurso e apoiando-se cada vez mais em máquinas eleitorais, financiamentos de grandes empresas e alianças com partidos mais conservadores, em detrimento de seus vínculos, cada vez mais fracos, com militantes políticos ligados aos movimentos populares. 
A perda de uma das bandeiras do petismo, a mobilização popular, foi um golpe duro para muitos militantes. Porém, quando o partido finalmente conseguiu emplacar Lula como presidente do país, logo vieram à tona as denúncias de corrupção do partido veiculadas pela mídia como o "escândalo do Mensalão". A dimensão alcançada pelo escândalo fez com que o petismo, ao ter outra de suas principais bandeiras maculada, a da ética e transparência, se tornasse vazio de sentido, impactando de forma negativa vários militantes e simpatizantes mais antigos do PT, que acabaram se afastando do partido em maior ou menor grau:

Eu sempre fui militante do Partido dos Trabalhadores, uma época muito forte, partidária mesmo, ia para as reuniões de diretório... Ultimamente, de uns oito a dez anos para cá, senti muitos desencantamentos com o Partido dos Trabalhadores. Eu ainda acredito que dentro do partido tem coisas boas que ainda valem a pena preservar, então eu tento me ligar a alguns parlamentares ou pessoas (com as quais) eu tenho mais afinidade nas questões éticas e que ainda não tem no vale-tudo como jeito de se ganhar uma eleição, então eu sou (do partido) ainda nesse sentido. Eu vejo assim o nível dos debates políticos muito frágil, essa é uma das coisas que me levou a não ser mais aquela militante assídua de reuniões do partido, é porque eu não aguento mais esse tipo de papo, você vai lá e é aquela mesma... você vê que a coisa não avança. Você vai numa reunião dessas é mais para você entender por que o fulano está com o ciclano, por que que o ciclano agora está com o beltrano, entender esses conchavos políticos que não faz o meu jeito. Você vê lá, às vezes, o pessoal brigando por coisas muito pequenas, enquanto esquecem que tem uma região que precisa de um projeto político, de uma intervenção mais séria (Juçara Zottis, militante política e fundadora da Associação Cantareira, 2011).

Todo trabalhador acredita que o PT é por ele, quando na realidade a gente sabe que não tem nada a ver, né? Eles usam disso porque sabem que as pessoas, quando fala assim, quando se trata de trabalhador, todo mundo acredita que: "ele está falando de trabalhador, então ele está falando comigo, então é nele que eu vou". Só que a gente não tem aquele raciocínio lógico de que "quem vai sair beneficiado com isso vão ser eles e não a gente" (Vânia, 47 anos, 2011).

Olha, eu votei no PT um tempão bom, depois eu mudei, mas eu votei no PT um tempão, depois eu saí. Às vezes a gente vota muitos anos num partido, depois acha que... vê que... né? Votei no Lula por muitos anos (risos), muitos anos viu? Agora mesmo quando o Kassab entrou eu votei no Kassab, votei no Serra também, o Geraldo Alckmin eu acho competente... Mas por que que o 
senhor resolveu mudar assim ${ }^{9}$ (pausa) É... umas coisas assim... a razão... a gente estava assistindo... foi muita corrupção, foi muita corrupção... Mensalão, teve Mensalão de todo o tipo né? Então foi na época do Mensalão que o senhor decidiu mudar, é isso? Foi, foi (Raimundo, 53 anos, 2011).

Assim, a única coisa que passou a diferenciar o PT dos demais partidos foi a implementação de políticas voltadas para as classes populares, de modo que as pessoas que continuavam afirmando preferir o PT sempre o faziam com ressalvas, de forma mais pragmática e desencantada em comparação com o auge do petismo:

Eu voto no PT, para dizer pra você, não porque eu acho que eles são melhores, é assim, desde que comecei a votar, eu sempre votei no PT. Então, independente de quem está lá, eu estou votando no PT, porque eu ainda acho que, apesar dos pesares, é um partido do povo, então eu voto, mas não acreditando totalmente que ele vai melhorar minha vida, entendeu? (Dulce, 52 anos, 2011).

Então você diria que você é petista? Sim, diria sim, diria com toda firmeza, com tudo que há... alguns fatos não ajudam, alguns fatos que explodem aí, errados, apesar de algumas coisas erradas, é o partido que te dá segurança, não é muito burguês, entendeu? Não é um partido totalmente burguês, é um partido mais povo, que olha mais a classe trabalhadora. Mas é assim, sempre que a pessoa parte para um ideal diferente, sempre há alguma coisa que acontece e que faz voltar tudo de novo (Silvana, 38 anos, 2011).

\section{Decifrando o lulismo: insatisfação na periferia e redenção no Nordeste}

Se o declínio da cultura política encampada pelo Partido dos Trabalhadores durante os anos 1980, o petismo, poderia ser previsto pelas diferentes teorias existentes a respeito da moderação ideológica de partidos políticos à medida que estes se tornam mais competitivos (Kirchheimer, 1966; Katz e Mair, 1995; Panebianco, 2005), o surgimento do lulismo foi completamente inesperado. A reeleição de Lula em 2006, no segundo turno, com uma boa margem de folga em relação ao candidato da oposição, Geraldo Alckmin do PSDB, apenas um ano após a veiculação pela mídia do escândalo do Mensalão, surpreendeu muitos jornalistas e analistas políticos. Contribuiu para tal desfecho a imensa quantidade de votos vinda dos setores mais empobrecidos da sociedade, os quais demonstraram sua lealdade a Lula em 2010 com a vitória de sua sucessora, Dilma Rousseff (Kerbauy, 2011), um quadro técnico do PT praticamente desconhecido da população e que nunca havia disputado uma eleição.

Grande parte dos eleitores que passaram a votar em Lula em 2006 habita regiões empobrecidas do país, sobretudo o Nordeste brasileiro, em que o petismo teve pouca

\footnotetext{
${ }^{9}$ As falas em itálico são minhas.
} 
penetração em comparação com outros locais, principalmente com São Paulo, onde nasceu o partido (Terron e Soares, 2010). Em muitos desses lugares, por vezes chamados de "grotões do país", existem currais eleitorais de políticos conservadores que costumam atuar em partidos de direita (Mainwaring, Meneguello e Power, 2000), por meio de políticas clientelistas ou por vezes até mesmo semelhantes ao antigo coronelismo, como indica o depoimento de Maria Conceição, sergipana que migrou para a periferia de São Paulo na década de 1990:

Por que você votou no Collor e não no Lula em 1989? Porque naquela época eu morava em Sergipe, então eu dependia de... eu não falei para você que lá em Sergipe precisa de boiada, tem os seus bois lá? Como assim de boiada? Boiada é assim: tem dois políticos, aí, dependendo se você deve favor para um, você vai votar naquele. Então você votou no Collor por causa disso? É... mas vou falar um negócio para você, lá é mais negócio de partido ${ }^{10}$, aqui em São Paulo não tem negócio de partido da população, você vai lá e vota. Lá em Sergipe eu votava lá assim, é mais de partido, então não é que nem aqui, que você quer votar, vota em um lá, mas você pode votar em outro, entendeu? Não depende de política assim, e lá eu dependia de política. Aqui, por exemplo, esse ano eu votei na Dilma, mas eu não devo a cabeça para a Dilma e nem devo a cabeça para o Serra. Eu não devo a obrigação, eu fui lá e votei, está vendo. Lá em Sergipe, não, lá em Sergipe você deve uma obrigação. Lá em Sergipe não se falava muito no PT, lembra? Naquela época o PT não era falado como hoje, naquela época o PT era um partido pequeno, não tinha muito PT lá (Maria da Conceição, 43 anos, 2011).

Assim, se é possível considerar que o voto no PT nesses locais parece estar mais relacionado com o impacto material e simbólico do lulismo do que com a atuação da agremiação ${ }^{11}$, nas periferias de São Paulo o fenômeno do lulismo se manifesta de modo mais nebuloso.

Por um lado, todos os 17 moradores entrevistados no bairro da Brasilândia, ainda que não tenham participado de programas de transferência de renda entre 2011 e 2013, de modo análogo aos setores mais empobrecidos da população, também foram beneficiados pelas políticas do governo federal. Todos relataram melhoras expressivas em seus níveis de renda e potencial de consumo em comparação com o período anterior aos governos Lula, estavam empregados ou conseguiram se empregar durante o período da

\footnotetext{
10 Aqui, quando a entrevistada fala em "partidos", quer dizer "clãs" ou grupos políticos locais aos quais se deve lealdade, e não a partidos no sentido moderno do termo.

${ }^{11}$ A identificação com Lula por parte dos segmentos mais empobrecidos da população, concentrados no Nordeste do país, possui alguma relação com os programas de transferência de renda promovidos pelos governos petistas (Hunter e Power, 2007; Zucco, 2013; Rego e Pinzani, 2013). No entanto, isso talvez não seja a única explicação (Simoni Jr., 2016), e talvez nem mesmo a principal, tendo em vista a forte identificação simbólica de muitos nordestinos pobres com Lula (Cohn, 2012).
} 
pesquisa, possuíam carteira assinada, reconheceram que o bairro que moram vem passando por melhoras expressivas no que tange a maior oferta de serviços (agências bancárias, comércio) e urbanização (canalização de córregos, pavimentação de ruas e construção de moradias populares), e cerca de um terço dos entrevistados havia passado a habitar recentemente em apartamentos construídos pelo Programa de Aceleração do Crescimento (PAC) em conjunto com a prefeitura.

Por outro lado, a despeito de terem experimentado uma mobilidade social razoável, praticamente nenhuma das pessoas que entrevistei relacionava a melhora em seus padrões materiais com políticas do governo federal, nem mesmo aqueles que habitavam apartamentos do PAC. Na verdade, tais melhoras eram sentidas como um pequeno alívio em um cotidiano permeado por graves adversidades. Problemas que já existiam nas décadas de 1980 e 1990 permaneceram ou até mesmo pioraram, como a violência decorrente da proximidade com o crime organizado, as condições precárias de trabalho (alta rotatividade, terceirização e rotinas exaustivas), a falta de opções de lazer, a precariedade de serviços e equipamentos públicos, as dificuldades com a locomoção urbana, o aumento do custo de vida, o aumento do endividamento e a crescente especulação imobiliária que dificulta a locação e a compra de bons imóveis.

Desse modo, a despeito das melhoras materiais, os entrevistados continuavam a se sentir desprotegidos, isto é, continuavam a ser perpassados por uma insegurança estrutural que afeta de modo geral aqueles que fazem parte das classes trabalhadoras precarizadas (Savage, 2004). Tal insegurança se materializa de formas diversas, mas pode-se dizer que as principais, no caso dos entrevistados, se relacionavam principalmente com as dinâmicas de espoliação urbana (Kowarick, 2000; Harvey, 2014) e com as condições precárias de inserção no mercado de trabalho (Braga, 2012, 2015):

Fizeram aquele negócio do Minha Casa, Minha Vida e eu fui uma das pessoas que me iludi muito. Eu fui na Caixa pra tentar o Minha Casa, Minha Vida, só que como que eu vou comprar uma casa se eu tenho que pagar mais do que o que eu ganho? Se eu não tenho como comprovar uma renda? Então é muito bonitinho você chegar na televisão e dizer "fiz o programa Minha Casa, Minha Vida", mas por que todo mundo está aqui na favela, não é? Não veio ninguém aqui perguntar pra mim. Não dão oportunidade, entendeu? Eles tratam o pobre como bicho. Quando eles arrumam uma oportunidade, arrumam um negocinho lá no meio da mata, lá em Poá ${ }^{12}$, e como você vai vir trabalhar aqui? (Tatiana, 30 anos, 2011).

Que nem o exemplo da crise, a crise financeira afetou o país, vamos mandar não sei quantas pessoas embora, o que eles ganharam com isso? O país mais parado, poucas pessoas trabalhando. Muitas pessoas nas comunidades pararam, começaram a pegar latinha na rua, pegar plástico, umas pessoas

12 Poá é um município que faz divisa com o extremo da Zona Leste de São Paulo. 
ainda acabavam se envolvendo em droga, bebida, jogados na rua... O governo tem dinheiro, querendo ou não eles têm dinheiro, então eles tinham que segurar. Esse negócio da crise aí foi uma furada com as pessoas. Eu fiquei desempregado, correndo atrás de serviço, não arrumei nada, fiquei na rua, dependendo de bico, até pegar latinha eu acabei pegando (Jadson, 21 anos, 2011).

Nesse sentido, o conceito de "precariado" (Braga, 2012) acabou se mostrando muito mais acertado do que a ideia de "nova classe $C$ ". Mesmo entre aqueles que conseguiram acesso a salários melhores e escolaridade mais alta durante os governos Lula, a quem o sociólogo Jessé de Souza (2010) chamou de "batalhadores", a sensação era de que, a despeito de todo esforço, sangue, suor e lágrimas que poderiam ser mobilizados para ascender socialmente, parecia ser impossível avançar um centímetro em direção a um padrão de classe média real. Esse era o caso de Eliana, que havia se graduado em comércio exterior, mas ganhava por mês menos que sua mãe que trabalhava como empregada doméstica, e de Neide, uma professora não concursada de escola pública que precisava trabalhar em duas escolas para ganhar cerca de dois salários mínimos mensais e ainda assim precisou se mudar para o município de Franco da Rocha pois não conseguiu juntar dinheiro suficiente para sair da invasão em que morava e comprar uma casa na Brasilândia. Assim, ainda que houvesse uma melhora nos padrões de vida das pessoas, as desigualdades sociais pareciam apenas continuar a ser repostas:

O nosso país não nasceu com a igualdade. Vai melhorar a qualidade de vida, mas a igualdade nunca (risos). Querendo ou não o governo pode estar roubando mas ele tá dando melhora de vida, tá dando oportunidade, entendeu? Que nem hoje, para eu ir no Shopping Alphaville, tá fácil, o ônibus passa na porta da minha casa, porque o governo tá dando essa ampla expansão de eu chegar até lá, então eu não dependo de um carro pra ir até lá, eu posso ir de ônibus, só que construíram outro shopping (risos), e nesse eu não vou. As pessoas estão ficando consumistas, estão tendo carros, acesso a shoppings, lojas, só que elas compram em 60 vezes, então tem pessoas que devem a vida duas vezes. Na verdade, o pobre não está tendo nada, quem está ganhando são os empresários. As lojas te dão a liberdade de ter, mas você pode manter? Eu conheci um moleque que o pai dele tem dinheiro, ele também. Pra comprar um tênis de 600 reais ele espera o ano inteiro, eu tenho dois. Ele tem uma renda de quinze mil, mas eu vejo no pé dele e falo: "Ah! Se você pode, eu também posso", vou lá e compro. A gente se repara com ele assim: ele é rico, eu sou pobre, mas eu tenho uma coisa da mesma forma que ele. Tudo meu é parcelado. Você tá vendo a diferença? (Leandro, 24 anos, 2011). 
Essa nova classe média ${ }^{13}$ que o governo fala nada mais são do que consumidores, não é uma classe média que tem condições, ela tem porque o governo facilita, a própria sociedade facilita. Mas, se você olhar a conta dela, é tudo endividado, no futuro vai ser só endividados, no futuro não vai ter gente que tenha. Porque todo mundo tem que ter, eu concordo, só que a forma que eles fazem engana, porque você paga num produto três vezes mais (Silene, 38 anos, 2011).

Todos os entrevistados, a despeito de suas diferenças, estavam em um estado de permanente insatisfação e tensão, a inquietação operária apontada por Ruy Braga, que não encontrava canais políticos institucionais de expressão, tendo em vista a perda da centralidade das associações e movimentos populares nas periferias que se organizavam em torno do petismo em décadas anteriores (Feltran, 2011). As escolhas eleitorais, ao contrário do que existia nos anos 1980, auge do petismo, eram realizadas em um cenário político percebido como distópico. Os políticos, os partidos e o sistema político de modo geral eram vistos como sendo essencialmente corrompidos, de modo que, ainda que existisse algum candidato que parecesse ter boas intenções, pouco poderia ser feito para gerar uma mudança que impactasse de forma importante a vida das classes trabalhadoras:

Eu voto porque é uma obrigação, mas não que você espera nada de ninguém, porque nunca muda nada. Aumenta o salário, aumenta também a condução, aumenta o gás, aumenta a gasolina, aumenta tudo. Não adianta, né. Pelo menos assim, se eles melhorassem ônibus, essas coisas. Nossa, meu pai do céu! Nunca melhora nada. Então a gente vota porque é obrigado. Você vê o tanto que o salário da gente sobe, o quanto o salário deles sobe? Então a gente sabe, qualquer um que você colocar lá dentro eles vão fazer o mesmo... (Aparecida, 41, anos, 2013).

Mudar não vai mudar mesmo. Porque, você veja bem, quando a pessoa entra lá, tem que fazer praticamente o que os outros já falaram, né, tudo combinado. Se não fez... um sozinho não pode. É que nem um passarinho quando ele tem o ninho dele, né? Um não deixa o outro fazer um ninho onde ele está, se os outros não concordarem, aquele passarinho não faz. É bem por aí (Cleuza, 58 anos, 2013).

Contudo, a despeito do declínio do petismo e do estreitamento de horizontes das classes trabalhadoras que habitam a periferia de São Paulo, os votos angariados pelo PT nos bairros de periferia da cidade ao longo do tempo aumentaram em vez de diminuir. Mesmo após o episódio do chamado Mensalão, o qual provocou uma queda momentânea na taxa de identificação partidária do PT (Venturi, 2010), os moradores da cidade de São

\footnotetext{
13 É interessante chamar a atenção para o fato de que nenhum dos entrevistados, a despeito da ascensão social, se autoclassificava como "classe C", "nova classe C", "classe média" ou "nova classe média", mas sim como "pobres", "povo" e "trabalhadores".
} 
Paulo com os menores níveis de renda e escolaridade continuaram votando de forma sistemática no partido (Limongi e Mesquita, 2008), aparentemente até 2012, quando o petista Fernando Haddad foi eleito prefeito da cidade. Mas, tendo em vista o cenário de distopia e insatisfação permeado pelo declínio do petismo, por que então as pessoas continuariam a votar no PT em eleições majoritárias, especialmente para a presidência?

Eu prefiro o PT, por mais coisa errada que eles façam, eles pensam um pouquinho nos pobres. Tudo bem que quando eles pensam nos pobres, eles pensam "o voto vai primeiro", porque pobre tem mais filho, tem mais gente pra votar. Mas eu gosto do PT não é só por isso não, é que eu brinco muito, mas é por causa da minha cidade lá no Nordeste, o PT fez muito lá. Então, muita gente pode dizer assim "ah, o PT fez uma esmola no Nordeste", mas se você for para o Nordeste, como eu passei 15 dias quando eu fui buscar minhas filhas, você vai dizer "o PT é um deus grego". Por isso que eu tiro o chapéu pro povo do Nordeste, o povo do Nordeste idolatra o PT. Porque o que eu tenho aqui pro povo do Nordeste é como se eu fosse milionária, e eu passo o maior sufoco. (...) E por que você acha que eles fizeram e os outros não? Eu acho que foi mais pelo presidente Lula, pela condição de vida que ele teve, eu acho que foi por isso que ele fez. O povo, todo mundo gostava dele. Eu gosto, eu gosto porque ele fez alguma coisa pelo meu povo, não foi nem por mim, mas foi pelo meu povo (Tatiana, 30 anos, 2011).

Por que eu votei no Lula? Porque eu vi que ele realmente... o Nordeste coitado do Nordeste, o Nordeste não comia, gente, era aquela pobreza danada, e aí eu votei no Lula por essa questão... comeu-se direito, pelo menos o pobre estava conseguindo comer. E eu votei no Lula nos dois mandatos dele. No Nordeste o Lula é considerado como um Deus, eu fui ao Nordeste no ano retrasado, e, assim, você não pode falar mal do Lula, você arruma briga, eles enfrentam mesmo, uma pessoa lá me falou assim: "aqui a gente glorifica o Lula, o Lula aqui para a gente é um Deus" (Eliana, 30 anos, 2011).

O Lula trabalha mais para a população mais pobre, é uma pessoa humilde, é uma pessoa que ganhou, mas você não viu assim empolgado de tudo. Eu acho que ele não mudou em nada depois, se fosse outra pessoa pobre, nossa, não ia nem ligar. Ele não, ficou a mesma pessoa, no meio do povão não usou segurança, não mudou, continua popular. Ele inventou muita coisa para a população pobre, em São Paulo não, mas lá para o Nordeste ele fez bastante coisa. Há uns dois anos atrás eu fui pra lá, muita coisa melhorou lá por causa dele, então eu acho ótimo. Aquelas pessoas às vezes não tinham nem o que comer... aquele negócio de renda mínima, eu não tenho, não me ajudou, mas ajudou muita gente lá que é pobre e depende desse dinheiro (Lourdes, 43 
anos, 2011).

Eu votei no Lula porque ele passou uma situação bacana. Eu cheguei a ir nos comícios dele, nossa... fomos eu e a minha tia lá da Freguesia do Ó14: "Vamos lá no comício do Lula? Vamos!". Eu cheguei a ir em vários comícios dele e ele passava uma popularidade que encantava! Até hoje né? E aí eu votei nele por isso. Ele passava uma segurança... Eu achava que ele gostava de nós pobres, ele gosta de pobre. Pela simplicidade dele, pelo jeito dele falar, pela forma que ele tratava, podia estar enganada, mas eu acho que ele foi bom, bom negociador, tem muita lábia, né, ele vai lá e resolve, entendeu? O que tiver que fazer ele vai lá, domina e faz. O que é incrível é isso, né, que ele tem lábia. Ele tem segurança naquilo que ele quer. E isso ele passou, foi muito importante. Muita gente o criticou, mas eu acreditei muito, sempre votei no Lula (Silvana, 38 anos, 2011).

Quando foi a eleição daquele Collor, nossa, logo de cara eu já falei: "nele eu não voto nunca". No Lula eu, nossa, votei nele várias vezes. Você gosta do Lula? Gosto, porque ele é uma pessoa pobre, uma pessoa que batalhou, passou pela pobreza, então, a pessoa para saber o que é um pobre, ele tem que ter sido pobre. Ele sabe se colocar na pele dos outros. $E$ por que você não gosta do Collor? Porque ele era muito riquinho, muito bobinho. Então você sempre gostou do Lula desde 89? Sempre mesmo, desde as histórias que a gente via que ele era metalúrgico, essas coisas, sempre pensava assim "ele deve ser uma boa pessoa, nordestino, sofreu muito, deve saber mais ou menos o que os outros passam" (Nilza, 41 anos, 2011).

Ainda que os cientistas políticos Peixoto e Rennó (2011) tenham apontado uma correlação positiva entre mobilidade social e voto em Dilma Rousseff em 2010, nenhum dos entrevistados afirmou ter votado na ex-presidente por esse motivo. As medidas implementadas pelo governo federal que beneficiaram o precariado das periferias das grandes cidades, como os aumentos do salário mínimo, a criação de empregos ou mesmo a construção de moradias populares, não foram citadas por nenhum dos entrevistados como explicação para a preferência por Lula e/ou pelo PT, apesar de todos terem relatado uma melhora de seus níveis de renda e consumo. As razões que cerca de dois terços dos entrevistados alegaram para justificar sua adesão a Lula e ao PT, como bem ilustram as falas acima, referiam-se ao aspecto simbólico presente no lulismo. Lula representaria de verdade as pessoas mais pobres, as quais habitavam as regiões mais empobrecidas do país, especialmente no Nordeste, de modo que os moradores da Brasilândia acabavam por se sentir parte de uma mesma coletividade, "os pobres", à qual também pertenceriam os nordestinos e o próprio Lula, o que por si só explicaria a confiança e a lealdade depositadas no ex-sindicalista e, em boa medida, a preferência pelo PT.

\footnotetext{
14 Bairro vizinho da Brasilândia.
} 
Essa vinculação simbólica dos trabalhadores que moram nas periferias de São Paulo e a população pobre do Nordeste ocorre, em grande medida, em função do passado dos primeiros, os quais, como Lula, vieram do Nordeste para trabalhar em São Paulo, como é o caso de 10 dos 17 entrevistados. Inclusive, nesse sentido, é particularmente interessante o caso de Raimundo, metalúrgico de origem baiana, que após o Mensalão perdeu completamente a fé no Partido dos Trabalhadores e passou a votar sistematicamente na oposição ao partido, mas afirmou que votaria novamente em Lula para um terceiro mandato pelo que ele teria feito pelo povo nordestino. No entanto, mesmo alguns entrevistados que não tinham vindo de estados nordestinos, mas de regiões empobrecidas de Minas Gerais, possuíam uma identificação similar pois tiveram trajetórias análogas.

\section{O futuro do lulismo: caminhando sobre gelo fino}

A despeito da crise política iniciada em 2013 e que se agravou com o impedimento de Dilma Rousseff, o lulismo continua vivo, como foi apontado anteriormente. Assim, é possível pensar que a lealdade dos mais pobres, especialmente daqueles que habitam o Nordeste, se mantém razoavelmente inabalada, considerando o impacto do lulismo na região e a identificação simbólica direta com Lula. No entanto, tendo em vista que os votos oriundos da população nordestina e/ou mais pobre do país não são suficientes para eleger um presidente, muito provavelmente o futuro do lulismo recaia nos votos das classes populares que habitam as grandes cidades. Mas quão fortes seriam afinal os vínculos do lulismo nas periferias? Ainda que pesquisas qualitativas sejam de difícil generalização, acredito que, ao menos no que tange à cidade de São Paulo, é possível esboçar algumas hipóteses. À primeira vista, a partir da exposição dos dados realizada aqui, seria possível imaginar que o lulismo teria conquistado uma adesão razoável entre os moradores da periferia, contudo, acredito que essa adesão é volúvel, e, nesse sentido, concordo com o diagnóstico realizado por Ruy Braga no que tange à existência de um consentimento passivo do precariado em relação ao lulismo, que, no caso dos moradores da periferia de São Paulo, se basearia principalmente nos aspectos simbólicos referidos acima, mas que seria instável e possuiria fragilidades importantes.

A primeira fragilidade do lulismo na periferia residiria na ausência da percepção do impacto positivo causado pelas políticas do governo federal em suas vidas durante os governos Lula. Assim, se a população nordestina reconhece os benefícios das políticas realizadas pelo governo federal, os moradores de bairros de periferia de São Paulo nem sequer relacionaram as políticas que os beneficiaram com a melhora de seus níveis de renda e consumo. Dessa forma, se as possibilidades de mudança dentro da ordem que foram oferecidas pelo lulismo na época talvez sejam suficientes para que os setores mais empobrecidos da população, principalmente aqueles que residem no Nordeste, continuem aderindo ao lulismo por mais tempo por conta de uma combinação de fatores materiais e 
simbólicos, é mais difícil dizer o mesmo no que tange ao precariado que habita a periferia de São Paulo. Afinal, é difícil que a identificação simbólica que constatei na pesquisa, que foi iniciada no auge do lulismo e finalizada pouco depois das manifestações de junho de 2013, tenha permanecido da mesma forma tendo em vista o recrudescimento das crises política e econômica a partir de então, como parece apontar uma pesquisa realizada pelo Vox Populi em 2014:

O Bolsa Família envelheceu, não pode mais ser usado como o grande carrochefe das campanhas petistas. $E$ as críticas não são apenas da classe média conservadora, mas estão vindo especialmente da chamada nova classe C, justamente aquela que ascendeu na gestão do PT. Esses cidadãos alegam que pagam seus impostos, enquanto outros recebem as benesses do governo, por isso não querem mais ser identificados com os que ainda dependem do programa para sobreviver (Marcos Coimbra, Vox Populi, Estado de S. Paulo, fevereiro de 2014, grifos meus $)^{15}$.

Outra fragilidade recairia no comportamento político dos moradores mais jovens da periferia, que nasceram nos anos 1990. Esses jovens tiveram pouco ou nenhum contato com o petismo e, ao contrário dos moradores mais velhos, já nasceram em São Paulo, portanto não possuem vínculos mais fortes com o Nordeste ou as regiões miseráveis do Brasil e não partilham da trajetória específica de Lula (Costa, 2015; Pavez, 2015; Patta, 2017). Assim, a força simbólica do lulismo acaba tendo pouco impacto nesse segmento em comparação com as gerações mais velhas, tendo em vista que nenhum dos entrevistados que possuíam menos de 25 anos era particularmente entusiasmado com Lula e/ou com o PT.

Por fim, a contraditória política de alianças do PT, unida à decepção com as denúncias de corrupção, tende a enfraquecer o impacto do lulismo na periferia de São Paulo no que diz respeito ao voto em candidatos que sejam do PT. Durante as eleições municipais de 2012, a aliança realizada entre o Partido dos Trabalhadores e seu adversário político histórico, Paulo Maluf (PP), fez com que Eliana, petista e fã da gestão de Erundina na prefeitura, ficasse desapontada com Lula e com o partido:

Na época da Erundina o ensino era muito bom também, as coisas eram mais firmes. Uma vez ela visitou a escola, eu era novinha, eu acho que eu tinha uns 9, 10 anos... pra mim a Erundina foi a melhor. Aí depois passou muito tempo veio aquele Pitta lá, que acabou morrendo, ladrão também, que foi coisa do Maluf, não é? Se fosse a Erundina a vice do Haddad, ele teria o meu voto, porque aí, se ele saísse, ficava a nossa vice Erundina. Mas ela não

\footnotetext{
15 Disponível em: <http://politica.estadao.com.br/noticias/geral,bolsa-familia-pode-deixar-de-ser-trunfodiz-analista,1135856>. Acesso em: 26 fev. 2018.
} 
aceitou... ${ }^{16}$. Por causa da aliança com o Maluf, não é? Eu acho que ela está certíssima. Porque o Lula devia tomar vergonha na cara dele, tomar vergonha e não ter feito aquilo, porque ele viu o que o Maluf fez. Então eu achei a atitude dela muito boa. Mulher de opinião, pra mim, está certíssima. O Lula não, mesmo assim ele quis, porque o Maluf também, lógico, o que ele está querendo é aliança com alguém, ele está correndo daqui, está correndo de lá, vamos dizer que é como se fosse um Collor, entendeu? Eu acho que ela fez certo. Esses dias mesmo a minha mãe estava falando, "ah, se bobear, esse Russomano acho que vai ganhar". Porque a gente fica tão frustrada algumas vezes, igual agora com o Lula, a gente fica frustrada. Então isso vai te deixando... o povo vai ficando triste, essa é a verdade. O povo vai começar a anular, não vota, vota em branco (Eliana, 30 anos, 2012).

Celso Russomano, apesar de ter conquistado muitos votos na periferia de São Paulo, não conseguiu ir para o segundo turno das eleições, porém, isso se deveu menos ao mérito do PT e mais ao amadorismo de sua candidatura. Ao final do período de campanha, o ex-malufista propôs que a tarifa de ônibus fosse proporcional à distância percorrida, o que obviamente prejudicaria a população mais pobre que precisa percorrer grandes distâncias de ônibus para chegar ao trabalho, o que fez com que suas intenções de voto despencassem rapidamente. Assim, ainda que a previsão da mãe de Eliana não tenha se concretizado, Russomano, cujo partido, é importante frisar, fazia parte na época da coalizão do governo federal, contou com uma votação não desprezível de 1.324.021 votos, somando $21,6 \%$ das preferências dos eleitores de São Paulo ${ }^{17}$. Nesse sentido, é interessante apontar a facilidade com que os entrevistados, mesmo aqueles que gostam de Lula e declaram preferência pelo PT, como Tatiana, possuem em votar em candidatos que se apresentam como "novos", independentemente do partido de origem:

Em 2004, a Marta disputou a reeleição no segundo turno com o Serra, você lembra em quem você votou? Eu votei na Marta. Em 2008, que foi a última eleição, no segundo turno, foi a Marta contra o Kassab, você lembra quem você votou? Kassab, porque eu achei que ele ia trazer melhorias né, mas eu fiquei meio decepcionada com ele. Na época eu votei nele porque eu pensei: "não, vamos mudar, vamos ver se ele vai fazer melhorias mesmo". Porque ele fez uma propaganda até muito bonita, né? Mas eu acho que ele deixou a desejar, eu fiquei meio revoltada assim, com essa situação das casas terem inundado, e o descaso, acho assim que é um descaso demorar com esse auxílio aluguel, demorar com lugar pra pôr a pessoa (Tatiana, 30 anos, 2013).

\footnotetext{
${ }^{16}$ Luíza Erundina recusou ser candidata a vice-prefeita na candidatura de Fernando Haddad do PT alegando discordância com a aliança realizada entre o PT e o Partido Progressista, partido do adversário histórico do petismo em São Paulo, Paulo Maluf.

17 Ver <http://placar.eleicoes.uol.com.br/2012/1turno>. Acesso em: 26 fev. 2018.
} 
Tatiana, apesar de ter declarado preferência pelo PT e por Lula, deixou de votar em Marta Suplicy, candidata do PT, para a eleição municipal em 2008, em favor de Gilberto Kassab, então filiado ao Democratas. Tal comportamento foi seguido por vários moradores de periferia naquele ano, o que acabou fazendo com que Kassab ganhasse a eleição na época, porque foi capaz de fazer uma "propaganda muito bonita", como confirmou a análise do cientista político Jairo Pimentel Jr., especialista em impacto emocional das campanhas no voto ${ }^{18}$. Inclusive, o pressentimento de Eliana de que o povo ficaria cada vez mais decepcionado e começaria a anular o voto se refletiu na escolha de Tatiana nas eleições municipais de 2012, quando afirmou ter votado em branco para todos os cargos como forma de protesto:

Eu votei tudo em branco, porque eu estou muito indignada com todo mundo. Eu ia votar no Tiririca, mas ele não foi candidato de novo pra deputado federal. Mas se tivesse Tiririca, eu ia votar no Tiririca, porque o Tiririca ganhou com milhões de votos e eu acho que as autoridades não entenderam ainda por quê. Não é porque ele sabia tudo de política, é tipo um protesto votar no Tiririca. Ia votar nele de novo, protestar, né? (Tatiana, 30 anos, 2013).

O afã de protestar contra os políticos de modo geral esboçado por Tatiana no final de 2012 acabou se espraiando para outros segmentos da população e se materializando nos anos seguintes nas manifestações de junho de 2013. Inclusive, é bom lembrar que Dilma perdeu para Aécio no bairro da Brasilândia em 2014 e dois anos depois, em 2016, os votos vindos das periferias ajudaram a eleger João Dória para a prefeitura da capital, candidato do PSDB que nunca havia disputado uma eleição e que conseguiu uma inédita vitória no $1^{0}$ turno. Assim, a despeito da existência de fortes vínculos simbólicos entre Lula e boa parte dos moradores da periferia de São Paulo, o lulismo parece caminhar sobre gelo fino.

Camila Rocha - Departamento de Ciência Política, Universidade de São Paulo, São Paulo, São Paulo, Brasil. E-mail: <camilarocha44@gmail.com>.

\section{Referências bibliográficas}

BRAGA, R. A política do precariado: do populismo à hegemonia lulista. São Paulo: Boitempo Editorial, 2012.

BragA, R. A pulsão plebeia. Trabalho, precariedade e rebeliões sociais. São Paulo: Alameda, 2015.

CABANES, R., et al. (orgs.). Saídas de emergência. Ganhar/perder a vida na periferia de São Paulo. São Paulo: Boitempo Editorial, 2011.

18 Ver em: <http://g1.globo.com/Noticias/Politica/0,,MUL803847-5601,00-

PROPAGANDA+DE+KASSAB+EMOCIONOU+ELEITOR+DIZ+CIENTISTA.html>. Acesso em: 26 fev. 2018. 
CoHN, A. Cartas ao presidente Lula: Bolsa Família e direitos sociais. São Paulo: Azougue, 2012.

CostA, H. "Entre o lulismo e o ceticismo: um estudo de caso com prounistas de São Paulo".

Dissertação de Mestrado, FFLCH-USP, São Paulo, 2015.

Diniz, E.; Boschi, R. Empresários, interesses e mercado. Dilemas do desenvolvimento no Brasil. Belo Horizonte: Editora UFMG, 2004.

FeltRAn, G. S. Desvelar a política na periferia: histórias de movimentos sociais em São Paulo. São Paulo: Humanitas, 2005. Unesp, 2011.

Fronteiras de tensão: política e violência nas periferias de São Paulo. São Paulo: Editora

FRIzzo, D. "Da classe média à periferia? O PT nas eleições municipais paulistanas (1996-2012)". Dissertação de Mestrado, FFLCH-USP, São Paulo, 2013.

HARVEY, D. Cidades rebeldes. Do direito à cidade à revolução urbana. São Paulo: Martins Fontes, 2014.

HUNTER, W.; POWER, T. "Rewarding Lula: Executive Power, social policy and the Brazilian elections of 2006". Latin American Politics and Society, vol. 49, n 1, p. 1-30, 2007.

KATZ, R.; MAIR, P. "Changing models of party organization and party democracy: the emergence of the cartel party". Party Politics, vol. 1, n 1, p. 5-28, 1995.

KeRBAUY, M. T. "Os programas de transferência de renda e o voto regional nas eleições presidenciais de 2010". Opinião Pública, vol. 17, n² 2, p. 477-492, 2011.

KIRCHHEIMER, O. "The transformation of the Western European party systems". Political Parties and Political Development, p. 177-200, 1966.

KowARICK, L. Escritos urbanos. São Paulo: Editora 34, 2000.

LAMOUNIER, B.; SOUZA, A. A classe média brasileira: ambições, valores e projetos de sociedade. São Paulo: Elsevier, 2010.

LIMONGI, F.; MESQUITA, L. "Estratégia partidária e preferência dos eleitores: as eleições municipais em São Paulo entre 1985 e 2004". Novos Estudos Cebrap, no 81, p. 49-67, 2008.

MACEDo, C. C. Tempo de gênesis: o povo das Comunidades Eclesiais de Base. São Paulo: Brasiliense, 1986.

Mainwaring, S.; Meneguello, R.; Power, T. Partidos conservadores no Brasil contemporâneo: quais são, o que defendem, quais são suas bases. Rio de Janeiro: Paz e Terra, 2000.

NERI, M. (coord.). A nova classe C. Rio de Janeiro: FGV/Ibre, CPS, 2008.

Panebianco, A. Modelos de partido: organização e poder nos partidos políticos. São Paulo: Martins Fontes, 2005.

PATTA. C. "Contestando a ordem: um estudo de caso com secundaristas da Zona Leste paulistana". Dissertação de Mestrado em Ciência Política, FFLCH-USP, São Paulo, 2017.

PAVEz, T. "Crime, trabalho e política: um estudo de caso entre jovens da periferia de São Paulo". Tese de Doutorado, FFLCH-USP, São Paulo, 2015. 
PETISMO E LULISMO NA PERIFERIA DE SÃO PAULO: UMA ABORDAGEM QUALITATIVA

Peixoto, V.; Rennó, L. "Mobilidade social ascendente e voto: as eleições presidenciais de 2010 no Brasil". Opinião Pública, vol. 17, n² 2, p. 304-332, 2011.

PochmanN, M. Nova classe média? O trabalho na base da pirâmide social brasileira. São Paulo: Boitempo Editorial, 2012.

POWER, T. Political right in postauthoritarian Brazil: elites, institutions, and democratization. University Park: Penn State Press, 1997.

Rego, W.; Pinzani, A. Vozes do Bolsa Família: autonomia, dinheiro e cidadania. São Paulo: Editora Unesp, 2013.

Samuels, D. "As bases do petismo". Opinião Pública, vol. 10, n² 2, p. 221-241, 2004.

Savage, M. Classe e história do trabalho. In: Batalha, C.; Silva, F.; Fortes, A. (orgs.). Culturas de classe. Campinas: Editora da Unicamp, 2004.

SeCco, L. História do PT. Cotia: Ateliê Editorial, 2011.

Simoni JR., S. "Competição eleitoral e política distributiva no Brasil: (re)avaliando o efeito dos programas de transferência de renda". Anais Eletrônicos do $10^{\circ}$ Encontro da ABCP, 2016.

SINGER, A. Esquerda e direita no eleitorado brasileiro: a identificação ideológica nas disputas presidenciais de 1989 e 1994. São Paulo: Edusp, 2000.

Letras, 2012.

. Os sentidos do lulismo. Reforma gradual e pacto conservador. São Paulo: Companhia das

SofIATI, F. M. "Tendências católicas: perspectivas do cristianismo da libertação". Estudos de Sociologia, vol. 14, n²6, 2009.

SouzA, J. Os batalhadores brasileiros: nova classe média ou nova classe trabalhadora?. Belo Horizonte: Editora UFMG, 2010.

StAnding, G. O precariado. A nova classe perigosa. São Paulo: Autêntica Editora, 2013.

Terron, S.; SoARes, G. "As bases eleitorais de Lula e do PT: do distanciamento ao divórcio". Opinião Pública, vol. 16, n², p. 310-337, 2010.

VENTURI, G. "PT 30 anos: crescimento e mudanças na preferência partidária". Perseu, vol. 5, n²00, p. $196-214,2010$.

Zucco, C. "When payouts pay off: conditional cash transfers and voting behavior in Brazil 20022010". American Journal of Political Science, vol. 57, n 4, p. 810-822, 2013.

\section{Fontes consultadas}

Jornal Cantareira, edição de fevereiro/março de 2003, seção "De olho na história: vila Brasilândia: meio século de contradições".

Jornal Cantareira, edição de julho de 2003, seção "De olho na história: Terezinha, vila marcada por sofrimentos e alegrias".

Jornal Cantareira, edição de maio de 2003, seção "De olho na história: Jardim Guarani, coragem e esperança".

Relatório do Cenpec (Centro de Estudos e Pesquisas em Educação, Cultura e Ação Comunitária Centro de Referência e Memória) referente ao "Projeto Brasilândia", realizado entre 1999 e 2000. 


\section{Resumo}

Petismo e lulismo na periferia de São Paulo: uma abordagem qualitativa

O objetivo do presente artigo é analisar as percepções políticas e as escolhas eleitorais de eleitores da periferia de São Paulo que ascenderam socialmente durante os governos Lula, tendo em vista o declínio do petismo e o surgimento do lulismo. Eles teriam relacionado sua ascensão social com as políticas governamentais dos governos Lula? Seriam lulistas? Caso fossem, o que isso significaria e qual impacto teria em suas percepções acerca do Partido dos Trabalhadores? De acordo com os dados levantados a partir de uma série de entrevistas em profundidade realizadas junto a moradores do bairro da Brasilândia entre 2011 e 2013, as motivações da preferência pelo PT e/ou por Lula não foram de ordem material, mas sim de ordem simbólica, tendo em vista os benefícios recebidos pela população mais pobre que habita o Nordeste brasileiro. Contudo, a despeito de tal identificação, a adesão ao PT e ao lulismo na periferia possui fragilidades importantes.

Palavras-chave: Iulismo; petismo; São Paulo; cultura política

\section{Abstract}

Petismo and lulismo in a poor neighborhood of São Paulo: a qualitative approach

The aim of this article is to analyze the political perceptions and the electoral choices of the residents of a poor neighborhood of São Paulo called Brasilândia based on a series of in-depth interviews conducted between 2011 and 2013. Would these individuals relate their social ascent to the public policies implemented during the Lula Era? Would they be lulistas? If so, what would this mean, and what impact would it have on their perceptions of the Workers' Party (PT)? According to the data collected, the motivations for having preferences for the PT and/or Lula were not of a material nature, but rather of a symbolic one, since interviewees demonstrated a strong identification with the poor population that lives in the Brazilian Northeast. However, in spite of such identification, adherence to the PT and to Iulismo in São Paulo's poor neighborhoods has important fragilities.

Keywords: Iulismo; petismo; São Paulo; political culture

\section{Resumen}

Petismo y lulismo en la periferia de São Paulo: un enfoque cualitativo

El objetivo del presente artículo es, a partir de una serie de entrevistas a profundidad realizadas en el barrio de Brasilândia entre 2011 y 2013, analizar las percepciones políticas y las elecciones electorales de los habitantes de la periferia de São Paulo que ascendieron socialmente durante los gobiernos de Lula. ¿Habrían relacionado su ascenso social con las políticas gubernamentales de los gobiernos de Lula? ¿Sería lulista? Si fueran, ¿qué significaría y qué impacto tendría en sus percepciones acerca del Partido de los Trabajadores? De acuerdo con los datos levantados, las motivaciones por la preferencia por el PT y / o por Lula dadas por los entrevistados no fueron de orden material, sino de orden simbólico, teniendo en cuenta los beneficios recibidos por la población más pobre que habita el Nordeste brasileño. Sin embargo, a pesar de dicha identificación, la adhesión al PT y al lulismo en la periferia tiene fragilidades importantes.

Palabras clave: Iulismo; petismo; São Paulo; cultura política 
PETISMO E LULISMO NA PERIFERIA DE SÃO PAULO: UMA ABORDAGEM QUALITATIVA

\section{Résumé}

Petismo et lulismo dans les quartiers pauvres de São Paulo: une approche qualitative

Le but de cet article est d'analyser les perceptions politiques et les choix électoraux des résidents d'un quartier pauvre de São Paulo appelé Brasilândia basé sur une série d'entrevues réalisés entre 2011 et 2013. Ont-ils lié leur ascension sociale aux politiques publiques mises en œuvre pendant l'ère Lula? Seraient-ils des lulistas? Dans l'affirmative, qu'est-ce que cela voudrait dire et quel impact aurait-il sur leurs perceptions concernant le Parti des Travailleurs? Selon les données recueillies, les motivations pour avoir des préférences pour le PT et/ou Lula données par les personnes interrogées n'étaient pas de nature matérielle, mais plutôt d'ordre symbolique, puisqu'elles ont démontré une forte identification avec la population pauvre qui vit dans le nord-est Brésilien. Cependant, malgré cette identification, I'adhésion au PT et au lulismo dans les quartiers pauvres de São Paulo présente d'importantes fragilités.

Mots clés: Iulismo; petismo; São Paulo; culture politique

Artigo submetido à publicação em 11 de maio de 2017. Versão final aprovada em 20 de fevereiro de 2018.

Opinião Pública adota a licença Creative Commons CC-BY (cc) $\mathrm{Br}$ 